MEDIALOG: Jurnal IImu Komunikasi, Volume III, No. II, Agustus 2020, hlm 24-35

\title{
EFEKTIVITAS KOMUNIKASI GOOGLE CLASSROOM SEBAGAI MEDIA PEMBELAJARAN JARAK JAUH PADA MAHASISWA ILMU KOMUNIKAI UNIVERSITAS NEGERI JAKARTA ANGKATAN 2018
}

\author{
Wanda Hanifah ${ }^{1}$, K.Y.S. Putri ${ }^{2}$ \\ Program Studi Ilmu Komunikasi Fakultas Ilmu Sosial, Universitas Negeri Jakarta \\ Email: wandahanifah_ikom18s1@mahasiswa.unj.ac.id
}

\begin{abstract}
ABSTRAK
Dalam menghadapi pandemi Covid-19, mahasiswa Ilmu Komunikasi di Universitas Negeri Jakarta melakukan Pembelajaran Jarak Jauh (PJJ) dengan menggunakan salah satu media pembelajaran online, yaitu google classroom. Dengan memanfaatkan google classroom ini maka dosen dan mahasiswa akan tersambung secara digital. Dalam melakukan kegiatan pembelajaran, terdapat proses komunikasi untuk menyampaikan pesan edukatif dari dosen kepada mahasiswa, hal itu bertujuan agar pesan yang disampaikan oleh dosen dapat diterima dengan baik sehingga mempengaruhi pengetahuan dan perubahan perilaku mahasiswa, maka itu kesuksesan suatu kegiatan pembelajaran sangat bergantung pada efektivitas proses komunikasi yang terjadi dalam pembelajaran. Oleh karena itu tujuan penelitian ini adalah untuk mengetahui efektivitas google classroom sebagai media pembelajaran jarak jauh pada mahasiswa Ilmu Komunikasi Universitas Negeri Jakarta angkatan 2018. Jenis penelitian ini adalah deskriptif dengan pendekatan kuantitatif. Populasi dari penelitian ini adalah mahasiswa Ilmu Komunikasi Universitas Negeri Jakarta angkatan 2018 yang berjumlah 37 orang dengan 34 responden. Penelitian ini memiliki satu variabel, yaitu efektivitas komunikasi. Hasil dari penelitian ini menyatakan bahwa keenam dimensi efektivitas komunikasi yaitu dimensi penerima pesan, dimensi isi pesan, dimensi media komunikasi, dimensi format pesan, dimensi sumber pesan dan terakhir yaitu dimensi ketepatan waktu, memperoleh nilai rata-rata diatas 2,5\%. Hal ini menunjukkan bahwa google classroom sebagai media pembelajaran jarak jauh pada mahasiswa Ilmu Komunikasi Universitas Negeri Jakarta angkatan 2018 dinyatakan efektif.
\end{abstract}

Kata Kunci : Efektivitas Komunikasi, Google Classroom, Pembelajaran Jarak Jauh.

\section{THE EFFECTIVENESS OF GOOGLE CLASSROOM COMMUNICATION AS A DISTANCE LEARNING MEDIA IN COMMUNICATION STUDIES STUDENTS AT THE JAKARTA STATE UNIVERSITY CLASS OF 2018}

\begin{abstract}
In dealing with the Covid-19 pandemic, students of Communication Studies at Jakarta State University conducted Distance Learning (PJJ) using one of the online learning media, namely google classroom. By utilizing this google classroom, lecturers and students will be digitally connected. In conducting learning activities, there is a communication process to deliver educative messages from lecturers to students, it is intended that messages conveyed by lecturers can be well received so that it affects knowledge and changes in student behavior, so the success of a learning activity is highly dependent on the effectiveness of the communication process that happens in learning. Therefore the purpose of this study is to determine the effectiveness of Google classroom as a medium of distance learning in Communication Studies students at the Jakarta State University class of 2018. This type of research is descriptive with a quantitative approach. The population of this study is the Communication Sciences students of the State University of Jakarta in 2018, amounting to 37 people with 34 respondents. This study has one variable, namely communication effectiveness. The results of this study stated that the six dimensions of communication effectiveness are the dimensions of message recipients, dimensions of message content, dimensions of communication media, dimensions of message formats, dimensions of message sources and finally the dimensions of timeliness, obtaining an average value above 2.5\%. This shows that google classroom as a medium for distance learning in Communication Studies students at the State University of Jakarta in 2018 class was declared effective.
\end{abstract}

Keywords: Communication Effectiveness, Google Classroom, Distance Learning. 
Korespondensi: Wanda Hanifah. Universitas Negeri Jakarta. Jalan H.Amat 1,Kel Kukusan, Kec Beji, Kota Depok, 16425. No. HP, WhatsApp: $\mathbf{0 8 5 7 7 7 1 8 6 7 9 5}$ Email: wandahanifah_ikom18s1 @ mahasiswa.unj.ac.id

\section{PENDAHULUAN}

Pada abad ke-21 tepatnya pada awal tahun 2020, dunia digemparkan dengan berita tentang virus corona (Covid-19), virus ini sudah menyerang ratusan bahkan mencapai ribuan orang di 16 negara salah satunya di Indonesia. Penyebaran virus corona ini terjadi begitu cepat, ini adalah fenomena luar biasa yang terjadi pada awal tahun 2020, hampir semua kegiatan berskala besar ditunda dan bahkan dibatalkan. Tercatat pada tanggal 19 Maret 2020 sebanyak 214.894 orang terinfeksi virus corona, 8.732 orang meninggal dunia dan pasien yang telah sembuh sebanyak 83.313 orang (Aida, 2020).

Di Indonesia sendiri, pada tanggal 29 Februari sampai 29 Mei 2020, Pemerintah telah mengeluarkan status darurat bencana terkait pandemi covid 19 ini. dengan itu Pemerintah sudah melakukan penanganan Covid-19, yang dimana dapat memutus penularan infeksi virus ini, salah satunya adalah dengan mensosialisasikan kepada masyarakat untuk menerapkan social distancing. Social distancing ialah menjaga jarak setidaknya dua meter dari orang lain, tidak melakukan kontak langsung dengan orang lain dan menghindari kerumunan untuk mencegah penularan virus ini (Koesmawardhani, 2020) Dengan demikian, pemerintah sudah mengeluarkan peraturan yang dimana diwajibkan untuk bekerja, belajar dan beribadah dari rumah.
Dalam menghadapi pandemi Covid-19, mahasiswa Ilmu Komunikasi di Universitas Negeri Jakarta melakukan Pembelajaran Jarak Jauh (PJJ), dimana kegiatan pembelajaran ini dilakukan di rumah masing-masing. Kegiatan pembelajaran adalah proses yang mencakup kegiatan dosen dalam menyampaikan materi pembelajaran kepada mahasiswa.

Dalam melakukan kegiatan pembelajaran, terdapat proses komunikasi untuk menyampaikan pesan edukatif dari dosen kepada mahasiswa, hal itu bertujuan agar pesan yang disampaikan oleh dosen dapat diterima dengan baik sehingga mempengaruhi pengetahuan dan perubahan perilaku mahasiswa. Maka itu kesuksesan atau kelancaran suatu kegiatan pembelajaran sangat bergantung pada efektivitas proses komunikasi yang terjadi dalam pembelajaran.

Dengan melakukan Pembelajaran Jarak Jauh tersebut, mahasiswa pasti membutuhkan media pembelajaran yang dapat mewakili pertemuan dikelas dengan menerapkan metode tatap muka dengan metode pembelajaran yang lain. Dengan hadirnya media bukan berarti akan menjamin kesusksesan kegiatan pembelajaran, tetapi tanpa adanya media, kegiatan proses pembelajaran pun juga tidak dapat dilaksanakan dengan baik. Mahasiswa Ilmu Komunikasi Universitas Negeri Jakarta Angakatan 2018 melaksanakan kegiatan pembelajaran secara jarak jauh dengan menggunakan salah satu media pembelajaran 
online, yaitu Google Classroom. Pengertian Google Classroom sendiri adalah aplikasi berbasis open sources yang memiliki model seperti ruang kelas yang terhubung melalui koneksi internet (Faruq, Dafik, Suharto, Fatahillah, \& Murtikusuma, 2018).

Dengan memanfaatkan Google Classroom ini maka dosen dan mahasiswa akan tersambung secara digital. Dosen dapat menyampaikan materi tanpa harus saling bertatap muka dengan mahasiswa. Google Classroom juga dapat diakses kapan saja dan dimana saja seperti melalui ponsel, PC dan tablet yang berbasis android dan iOS. Penggunaan aplikasi google classroom berbasis open sources ini juga tidak dipungut biaya (Simanihuruk, et al., 2019).

Dengan melalui aplikasi Google Classroom dianggap bahwa tujuan pembelajaran akan lebih mudah untuk dipraktikkan. Dengan demikian, penggunaan Google Classroom ini sebenarnya mempermudah dosen dalam mengelola kegiatan pembelajaran dan menyampaikan pesan secara tepat, akurat dan aktual kepada mahasiswa (Hakim, 2016). Untuk mengoperasikan google classroom, pengguna diharuskan untuk mempunyai akun gmail, karena hal itu merupakan salah satu syarat untuk masuk kedalam halaman utama. Kemudian setelah masuk dengan menggunakan gmail, maka pengguna dapat membuat kelas belajar (Simanihuruk, et al., 2019).

Dalam aplikasi google classroom yang berbasis open sources ini pengguna juga dapat membuat beberapa kelas dengan menggunakan kode kelas sebagai keterangan kelas pembelajaran.
Lalu ketika pengguna sudah dapat membuat kelas belajar, otomatis pengguna juga dapat mengoptimalkan fitur fitur yang sudah tersedia pada google classroom, seperti assighnments, communication, grading, mobile application, time cost, privacy, dan archive course. Dengan fitur tersebut pengguna dapat membagikan materi pembelajaran, video pembelajaran, mengumpulkan tugas, melaksanakan kuis, melakukan diskusi terhadap materi dan lain sebagainya (Simanihuruk, et al., 2019).

Selanjutnya mahasiswa pun dapat masuk ke google classroom dengan menggunakan kode kelas yang sudah diberikan oleh masing-masing dosen. Dengan demikian, mahasiswa dapat mengikuti kelas sesuai dengan intruksi dari dosennya masing-masing.

Penelitian sebelumnya dilakukan oleh Sabran dan Edy Sabara dengann judul "Keefektifan Google Classroom Sebagai Media Pembelajaran”. Hasil penelitian tersebut menyatakan bahwa Google Classroom sudah cukup efektif dalam aspek perencanaan pembelajaran, perancangan dan pembuatan materi, penyampaian ataupun metode penyampaian pembelajaran, interaksi pembelajaran, dan evaluasi pelaksanaan pembelajaran (Sabran \& Sabara, 2019).

Selanjutnya penelitian lain yang dilakukan oleh Dhia Ghina Ramadhani Putri S dengan judul "Communication Effectiveness Of Online Media Google Classroom In Supporting The Teaching And Learnig Process At Civil Engineering University Of Riau". Hasil dari penelitian ini menunjukkan bahwa efektivitas Google 
Classroom di teknik sipil dianggap sangat efektif.

Ini telah dibuktikan oleh hasil data yang dikumpulkan diukur dengan enam indikator, yaitu Receiver, Konten, Media, Format, Sumber dan Waktu. Hasilnya sangat efektif dengan skala 4,36, yang berarti bahwa Google Classroom sangat efektif untuk digunakan dalam memberikan informasi di teknik sipil Universitas Riau (Putri, 2017).

Kemudian penelitian terdahulu yang dilakukan oleh Yoyon Efendi dan Nurul Utami dengan judul "Pengukuran Efektifitas Pembelajaran Menggunakan Media E-Learning Google Classroom (SMK Sulthan Muazzamsyah Pekanbaru)". Hasil dari penelitian tersebut menyatakan bahwa google classroom sebagai media e-learning yang dapat diterapkan di SMK Sulthan Muazzam Syah., google classroom dapat memudahkan dosen memberikan variasi pembelajaran tanpa harus tatap muka dikelas dan google classroom dapat memudahkan mahasiswa dalam mengetahui materi ajar dan penilaian secara transparan (Efendi \& Utami, 2019).

Berdasarkan penjelasan diatas, penulis tertarik untuk melakukan penelitian mengenai tingkat efektivitas google classroom dengan judul: Efektivitas Komunikasi Google Classroom Sebagai Media Pembelajaran Jarak Jauh Pada Mahasiswa Ilmu Komunikai Universitas Negeri Jakarta Angaktan 2018. Tujuan dari penelitian ini adalah untuk mengetahui efektivitas komunikasi google classroom sebagai media pembelajaran jarak jauh pada mahasiswa Ilmu Komunikasi Universitas Negeri Jakarta angkatan 2018.

\section{Efektivitas Komunikasi}

Efektivitas ialah unsur pokok untuk mencapai tujuan atau terget, yang dimana terget tersebut sudah ditentukan (Nova, 2018), jika dikaitkan dengan komunikasi maka efektivitas komunikasi ialah seberapa jauh target yang dicapai untuk menyampaikan suatu pesan oleh seseorang kepada orang lain. Proses komunikasi dikatakan efektif, apabila informasi yang disampaikan oleh pengirim pesan dapat diterima baik dan sesuai apa yang dimaksudkan oleh pengirim pesan, sehingga terjadi perubahan perilaku dari penerima pesan. Efektivitas melihat adanya kesamaan makna antara pengirim pesan dan penerima pesan terhadap simbol-simbol yang diteruskan. (Syabrina, 2018). Menurut Hardjana efektivitas komunikasi diukur oleh enam dimensi, yaitu: (Hardjana, 2000:23)

1. Penerima atau pemakai (receiver)

Pesan ialah objek yang diukur berdasarkan ketepatan siapa yang akan menerima pesan tersebut. Seorang penerima pesan dikatakan efektif apabila penerima pesan sesuai dengan penerima yang sudah diarahkan. jika penerima pesan sudah sesuai dengan penerima yang diarahkan oleh media tersebut, maka langkah selanjutnya untuk mengukur kefektivannya ialah melihat bagaimana kapasitas si penerima pesan dalam menggunakan media tersebut dalam memenuhi kebutuhan informasinya.

2. Isi pesan (Content) 
Isi pesan ialah kesesuaian dari tujuan komunikasi dengan informasi yang bersifat objektif dan akurat yang diterima oleh audiens.

\section{Media komunikasi (Media)}

Media komunikasi ialah media yang digunakan atau dimanfaatkan untuk proses penyampaian pesan sesuai dengan kebutuhan dan sesuai dengan apa yang diharapkan oleh pengirim pesan dan penerima pesan.

\section{Format Pesan (Format)}

Format pesan ialah bahwa format pesan disesuaikan dengan apa yang disampaikan oleh pengirim pesan kepada penerima pesan, yang dimana dilihat dari cara penyampaian isi pesannya, jelas, singkat, dan sederhana.

\section{Sumber Pesan (Source)}

Sumber pesan ialah mengenai kredibilitas sumber pesan yang dimana dapat dipertanggungjawabkan, sehingga pesan yang telah disampaikan dapat dipercaya.

\section{Ketepatan Waktu (Timing)}

Ketepatan waktu ialah bahwa pesan yang disampaikan oleh pengirim pesan akan diterima tepat waktu kepada penerima pesan, yang dimana waktu tersebut sudah disepakati.

\section{Teori New Media}

Teori new media merupakan sebuah teori yang dikembangkan oleh Pierre Levy dalam bukunya Cybercultur (Levy, 2001) yang mengemukakan bahwa new media merupakan teori yang membahas mengenai perkembangan media dari konvensional ke era digital. New media atau media baru disebut juga media digital. Menurut Dennis McQuail dalam bukunya Teori Komunikasi Massa, ciri utama new media adalah adanya saling keterhubungan, aksesnya terhadap khalayak individu sebagai penerima maupun pengirim pesan, interaktivitasnya, kegunaan yang beragam sebagai karakter yang terbuka, dan sifatnya yang ada di mana-mana (McQuail, 2011).

Istilah new media merupakan penggambaran karakateristik media yang berbeda dari yang selama ini ada. seperti televisi, majalah, koran, radio, dan koran dikategorikan sebagai media lama. Lalu media internet mengandung sifat interaktif yang dikategorikan sebagai media baru, sehingga pengistilahan new media bukan lah berarti media lama hilang menjadi media baru. Menurut Flew dalam (Watie, 2011) new media ialah media yang merekomendasikan digitalisasi, konvergensi, interaktivitas dan pengembangan jaringan terkait pembuatan pesan dan penyampaian pesannya. Keahlian new media dengan merekomendasikan interaktivitas ini memungkinkan pengguna dari new media dapat memilih informasi apa yang akan dikonsumsi, dan inilah yang merupakan konsep utama dari pemahaman tentang new media.

Media baru mengacu pada media digital di mana semua data diproses dan disimpan sebagai angka dan hasilnya disimpan sebagai cakram digital. Ada beberapa implikasi digitalisasi media, yaitu dematerialisasi atau memisahkan teks dari bentuk fisik, tidak memerlukan ruang besar untuk 
menyimpan data karena data dikompresi ke dalam ukuran yang lebih kecil, data mudah diakses dengan kecepatan tinggi dan mudah dimanipulasi (Watie, 2011).

\section{Google Classroom}

Google Classroom adalah bagian dari paket Google Apps for Education (GAFE) yaitu aplikasi produktivitas online yang dikemas untuk guru dan siswa ataupun dosen dan mahasiswa untuk pembelajaran dan kolaborasi online (Zhang, 2016). Google classroom ini gratis, tetapi harus digunakan di tingkat lembaga pendidikan. Sementara GAFE berisi banyak Google Apps populer seperti Gmail, Google Calendar, dan Google Drive, yang dapat diakses oleh siapa saja (Zhang, 2016).

Google Classroom hanya ditemukan di GAFE Ini menyediakan situs pusat untuk berkomunikasi dengan siswa ataupun mahasiswa, mengirim pengumuman, memulai diskusi, mendistribusikan, mengumpulkan tugas dan mengirim umpan balik. Beberapa kekuatan utama dari Google Classroom adalah fitur-fiturnya yang hemat waktu dan aplikasi yang mudah digunakan dan sederhana (Zhang, 2016). Adapun manfaat dari Google Classroom, yaitu :

1. Dapat dipersiapkan dengan mudah. Pengajar dapat menyiapkan kelas dan mengundang siswa atau mahasiswan dan asisten pengajar. Di halaman Kelas, mereka dapat berbagi informasi, tugas, dan materi.

2. menghemat waktu dan tidak menggunakan kertas.
Pengajar dapat membuat kelas, menugaskan tugas, berkomunikasi dan mengelola, semuanya di satu tempat.

3. Manajemen yang lebih baik.

Siswa atau mahasiswa dapat melihat tugas pada halaman tugas, dalam ruang kelas, atau pada kalender kelas. Semua materi kelas disimpan secara otomatis di folder Google Drive.

4. Meningkatkan komunikasi dan masukan.

Pengajar dapat membuat tugas, mengirim pengumuman, dan memulai diskusi kelas secara langsung. Siswa atau mahasiswa dapat berbagi materi satu sama lain dan berinteraksi dalam kelas atau melalui email. Pengajar juga dapat dengan cepat melihat siapa yang telah dan belum menyelesaikan tugas, dan segera memberikan nilai dan input waktu nyata.

5. Dapat bekerja dengan aplikasi yang Anda gunakan.

Seperti dengan Google Documents, Kalender, Gmail, Drive, dan Formulir.

6. Kelas yang terjangkau dan aman.

Karena disediakan gratis untuk sekolah, organisasi nirlaba, dan individu. Kelas tidak mengandung iklan dan tidak pernah menggunakan konten atau data siswa atau mahasiswa Anda untuk tujuan iklan.

\section{METODE PENELITIAN}

Jenis penelitian ini adalah penelitian deskriptif dengan menggunakan pendekatan kuantitatif. Menurut Malhotra (2010) penelitian deskriptif merupakan jenis penelitian yang bertujuan untuk 
menggambarkan atau mendeskripsikan suatu karakter maupun fungsi dasar. Metode dalam penelitian ini menggunakan metode survei, menurut Malhotra (2010) metode survei ialah metode penelitian dengan menggunakan kuesioner terstruktur yang diberikan kepada sampel populasi dan dirancang untuk memperoleh informasi spesifik dari responden. Dalam metode survei proses pengumpulan dan analisis data sosial bersifat sangat terstruktur dan mendetail melalui kuesioner sebagai instrumen pertama untuk mendapatkan informasi dari sejumlah responden yang diasumsikan mewakili populasi secara spesifik.

Populasi pada penelitian ini yaitu mahasiswa aktif program studi Ilmu Komunikasi Universitas Negeri Jakarta angkatan 2018 yang berjumlah 37 orang. Teknik penarikan sampel pada penelitian ini adalah sampel acak sederhana. Teknik sampel acak sederhana merupakan salah satu jenis probability sampling. Oleh karena itu, jumlah sampel pada penelitian ini ditentukan dengan menggunakan rumus Slovin. Rumus Slovin hanya digunakan untuk populasi yang diketahui jumlahnya, karena jumlah populasi penelitian ini diketahui, yaitu berjumlah 37 orang, maka dapat digunakan rumus Slovin sebagai berikut:

$$
\begin{gathered}
n=\frac{N}{1+N(d f)^{2}} \\
n=\text { Jumlah Sampel } \\
N=\text { Jumlah Populasi } \\
\mathrm{df}=\text { nilai kritis } \\
n=\frac{37}{1+37(0,05)^{2}} \\
n=33,8 \text { (dibulatkan menjadi } 34)
\end{gathered}
$$

Berdasarkan perhitungan menggunakan rumus slovin tersebut, maka jumlah sampel dalam penelitian ini adalah 34 orang mahasiswa aktif program studi Ilmu Komunikasi Universitas Negeri Jakarta angkatan 2018.

Penelitian ini mempunyai satu variabel penelitian yaitu efektivitas komunikasi. Pada variabel tersebut terdapat enam dimensi yang sudah dijelaskan pada pendahuluan diatas yaitu Penerima pesan (receiver), Isi pesan (Content), Media komunikasi (Media), Format Pesan (Format), Sumber Pesan (Source), dan Ketepatan

\begin{tabular}{|c|c|c|c|}
\hline Variabel & Dimensi & Indikator & Skala \\
\hline \multirow{6}{*}{$\begin{array}{l}\text { Efektivitas } \\
\text { Komunikasi }\end{array}$} & $\begin{array}{l}\text { 1.Penerima } \\
\text { pesan }\end{array}$ & $\begin{array}{ll}\text { 1. } & \text { Ketepatan } \\
& \text { penerima pesan }\end{array}$ & \multirow{6}{*}{ Interval } \\
\hline & 2.Isi pesan & 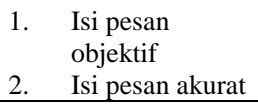 & \\
\hline & $\begin{array}{l}\text { 3.Media } \\
\text { komunikasi }\end{array}$ & $\begin{array}{ll}\text { 1. } & \text { Media } \\
\text { penyampaian } \\
\text { pesan sesuai } \\
\text { dengan } \\
\text { kebutuhan } \\
\text { Media } \\
\text { penyampaian } \\
\text { pesan sesuai } \\
\text { harapan antara } \\
\text { pengirim dan } \\
\text { penerima pesan. }\end{array}$ & \\
\hline & 4.Format pesan & $\begin{array}{ll}\text { 1. } & \begin{array}{l}\text { Format pesan } \\
\text { jelas }\end{array} \\
\text { 2. } & \begin{array}{l}\text { Format pesan } \\
\text { singkat }\end{array} \\
\text { 3. } & \begin{array}{l}\text { Format pesan } \\
\text { sederhana }\end{array} \\
\end{array}$ & \\
\hline & $\begin{array}{l}\text { 5.Sumber } \\
\text { pesan }\end{array}$ & $\begin{array}{l}\text { 1. Sumber pesan } \\
\text { dapat dipercaya }\end{array}$ & \\
\hline & $\begin{array}{l}\text { 6.Ketepatan } \\
\text { waktu }\end{array}$ & $\begin{array}{l}\text { Waktu sesuai } \\
\text { dengan kondisi }\end{array}$ & \\
\hline
\end{tabular}
Waktu (Timing). Setiap dimensi memiliki turunan yang disebut indikator. Indikator tersebut dapat dilihat pada tabel operasional konsep sebagai berikut.

Tabel 1 Operasional Konsep 


\begin{tabular}{|l|l|l|l|}
\hline & & \\
\hline
\end{tabular}

\section{HASIL DAN PEMBAHASAN}

Peneliti telah mengumpulkan data melalui penyebaran kuesioner kepada sampel yang telah ditentukan sebelumnya. Pada kuesioner terdapat sejumlah pernyataan yang dibuat berdasarkan indikator dari dimenasi-dimensi efektivitas komunikasi yang sudah dijelaskan pada tabel operasional konsep di atas. Berikut ini adalah tabel hasil per indikator :

Tabel 2 Ketepatan penerima pesan $\mathrm{n}=\mathbf{3 4}$

\begin{tabular}{|c|c|c|c|}
\hline Pernyataan & Frekuensi & Persentase & $\begin{array}{l}\text { Rata- } \\
\text { rata }\end{array}$ \\
\hline $\begin{array}{l}\text { 4= Sangat } \\
\text { setuju }\end{array}$ & 10 & $29,4 \%$ & \multirow{5}{*}{$3,26 \%$} \\
\hline $3=$ Setuju & 23 & $67,6 \%$ & \\
\hline $\begin{array}{l}2=\text { Tidak } \\
\text { setuju }\end{array}$ & 1 & $2,9 \%$ & \\
\hline $\begin{array}{l}1=\text { Sangat } \\
\text { tidak } \\
\text { setuju }\end{array}$ & 0 & $0 \%$ & \\
\hline Total & 34 & $100 \%$ & \\
\hline
\end{tabular}

Hasil pada tabel tersebut menunjukkan sebagian besar responden manjawab setuju dengan persentase $67,6 \%$ bahwa saat sedang melaksanakan pembelajaran jarak jauh, seorang penerima informasi dari media google classroom sesuai dengan penerima yang dituju oleh dosen.

Tabel 3. Isi pesan objektif n $=34$

\begin{tabular}{|l|c|c|c|}
\hline Pernyataan & Frekuensi & Persentase & $\begin{array}{c}\text { Rata- } \\
\text { rata }\end{array}$ \\
\cline { 1 - 3 } $\begin{array}{l}\text { 4= Sangat } \\
\text { setuju }\end{array}$ & 7 & $20,6 \%$ & \\
\cline { 1 - 3 } 3= Setuju & 23 & $67,6 \%$ & \multirow{2}{*}{$3,08 \%$} \\
\hline 2= Tidak & 4 & $11,8 \%$ & \\
\hline
\end{tabular}

\begin{tabular}{|c|c|c|}
\hline setuju & & \\
\hline $\begin{array}{l}\text { 1= Sangat } \\
\text { tidak } \\
\text { setuju }\end{array}$ & 0 & $0 \%$ \\
\hline Total & 34 & $100 \%$ \\
\hline
\end{tabular}

Hasil pada tabel diatas menunjukkan rata-rata responden menjawab setuju dengan persentase $67,6 \%$ bahwa pesan atau materi yang disampaikan oleh dosen di google classroom bersifat objektif yaitu sesuai dengan kenyataan.

Tabel 4. Isi pesan akurat $\mathrm{n}=\mathbf{3 4}$

\begin{tabular}{|c|c|c|c|}
\hline Pernyataan & Frekuensi & Persentase & $\begin{array}{l}\text { Rata- } \\
\text { rata }\end{array}$ \\
\hline $\begin{array}{l}4=\text { Sangat } \\
\text { setuju }\end{array}$ & 8 & $23,5 \%$ & \multirow{5}{*}{$3,02 \%$} \\
\hline $3=$ Setuju & 19 & $55,9 \%$ & \\
\hline $\begin{array}{l}2=\text { Tidak } \\
\text { setuju }\end{array}$ & 7 & $20,6 \%$ & \\
\hline $\begin{array}{l}\text { 1= Sangat } \\
\text { tidak } \\
\text { setuju }\end{array}$ & 0 & $0 \%$ & \\
\hline Total & 34 & $100 \%$ & \\
\hline
\end{tabular}

Hasil pada tabel diatas menggambarkan sebagian besar responden menjawab setuju dengan persentase $55,9 \%$ bahwa informasi atau pesan yang disampaikan oleh di google classroom bersifat akurat.

\section{Tabel 5. Media penyampaian pesan sesuai} dengan kebutuhan $\mathrm{n}=\mathbf{3 4}$

\begin{tabular}{|c|c|c|c|}
\hline Pernyataan & Frekuensi & Persentase & $\begin{array}{c}\text { Rata- } \\
\text { rata }\end{array}$ \\
\cline { 1 - 3 } $\begin{array}{c}\text { 4= Sangat } \\
\text { setuju }\end{array}$ & 9 & $26,5 \%$ & \\
\hline 3= Setuju & 23 & $67,6 \%$ & \multirow{2}{*}{$3,20 \%$} \\
\hline $\begin{array}{c}\text { 2= Tidak } \\
\text { setuju }\end{array}$ & 2 & $5,9 \%$ & \\
\hline
\end{tabular}




\begin{tabular}{|c|c|c|c|}
\hline $\begin{array}{c}\text { 1= Sangat } \\
\text { tidak } \\
\text { setuju }\end{array}$ & 0 & $0 \%$ & \\
\hline Total & 34 & $100 \%$ & \\
\hline
\end{tabular}

Hasil pada tabel diatas menunjukkan sebagian besar responden menjawab setuju dengan persentase $67,6 \%$ bahwa media google classroom ialah media yang tepat sesuai dengan kebutuhan dosen dan mahasiswa dalam mendukung pembejalaran jarak jauh.

Tabel 6. Media penyampaian pesan sesuai harapan antara pengirim dan penerima pesan $\mathrm{n}=\mathbf{3 4}$

\begin{tabular}{|l|c|c|c|}
\hline Pernyataan & Frekuensi & Persentase & $\begin{array}{c}\text { Rata- } \\
\text { rata }\end{array}$ \\
\cline { 1 - 3 } $\begin{array}{l}\text { 4= Sangat } \\
\text { setuju }\end{array}$ & 9 & $26,5 \%$ & \\
\hline 3= Setuju & 21 & $61,8 \%$ & \multirow{2}{*}{$3,11 \%$} \\
\cline { 1 - 3 } $\begin{array}{l}\text { 2= Tidak } \\
\text { setuju }\end{array}$ & 3 & $8,8 \%$ & \\
\cline { 1 - 1 } $\begin{array}{l}\text { 1= Sangat } \\
\text { tidak } \\
\text { setuju }\end{array}$ & 1 & $2,9 \%$ & \\
\cline { 1 - 3 } Total & 34 & $100 \%$ & \\
\hline
\end{tabular}

Hasil pada tabel diatas menunjukkan sebagian besar responden menjawab setuju dengan persentase $61,8 \%$ bahwa media google classroom ialah media yang yang tepat untuk memudahkan penyampaian pesan pada mahasiswa dalam mendukung pembelajaran jarak jauh.

Tabel 7. Format pesan jelas $\mathrm{n}=34$

\begin{tabular}{|l|c|c|c|}
\hline Pernyataan & Frekuensi & Persentase & $\begin{array}{c}\text { Rata- } \\
\text { rata }\end{array}$ \\
\hline $\begin{array}{l}\text { 4= Sangat } \\
\text { setuju }\end{array}$ & 3 & $8,8 \%$ & \\
\hline 3= Setuju & 20 & $58,8 \%$ & \multirow{2}{*}{$2,73 \%$} \\
\hline $\begin{array}{l}\text { 2= Tidak } \\
\text { setuju }\end{array}$ & 10 & $29,4 \%$ & \\
\hline
\end{tabular}

\begin{tabular}{|l|l|l|l|}
\hline $\begin{array}{l}\text { 1= Sangat } \\
\text { tidak } \\
\text { setuju }\end{array}$ & 1 & $2,9 \%$ & \\
\cline { 1 - 3 } Total & 34 & $100 \%$ & \\
\hline
\end{tabular}

Hasil pada tabel diatas menggambarkan ratarata responden menjawab setuju dengan persentase $58,8 \%$ bahwa setiap isi pesan atau informasi yang ada pada Google Classroom memberikan arti yang jelas.

Tabel 8. Format pesan singkat

$$
\mathbf{n}=\mathbf{3 4}
$$

\begin{tabular}{|l|c|c|c|}
\hline Pernyataan & Frekuensi & Persentase & $\begin{array}{c}\text { Rata- } \\
\text { rata }\end{array}$ \\
\hline $\begin{array}{l}\text { 4= Sangat } \\
\text { setuju }\end{array}$ & 2 & $5,9 \%$ & \\
\hline 3= Setuju & 21 & $61,8 \%$ & \multirow{2}{*}{$2,64 \%$} \\
\cline { 1 - 3 } $\begin{array}{l}\text { 2= Tidak } \\
\text { setuju }\end{array}$ & 8 & $23,5 \%$ & \\
\hline $\begin{array}{l}\text { 1= Sangat } \\
\text { tidak } \\
\text { setuju }\end{array}$ & 3 & $8,8 \%$ & \\
\hline \multicolumn{1}{|c|}{ Total } & 34 & $100 \%$ & \\
\hline
\end{tabular}

Hasil pada tabel diatas menunjukkan sebagian besar responden menjawab setuju dengan persentase $61,8 \%$ bahwa dosen menyampaikan isi pesan dengan singkat di google classroom sehingga mudah dipahami.

Tabel 9. Format pesan sederhana

$$
\mathrm{n}=\mathbf{3 4}
$$

\begin{tabular}{|l|c|c|c|}
\hline Pernyataan & Frekuensi & Persentase & $\begin{array}{c}\text { Rata- } \\
\text { rata }\end{array}$ \\
\hline $\begin{array}{l}\text { 4= Sangat } \\
\text { setuju }\end{array}$ & 5 & $14,7 \%$ & \\
\hline $\begin{array}{l}\text { 3= Setuju } \\
\text { 2= Tidak } \\
\text { setuju }\end{array}$ & 20 & $58,8 \%$ & \multirow{2}{*}{$2,88 \%$} \\
\hline $\begin{array}{l}\text { 1= Sangat } \\
\text { tidak } \\
\text { setuju }\end{array}$ & 0 & $0 \%$ & \\
\hline \multicolumn{1}{|c|}{ Total } & 34 & $100 \%$ & \\
\hline
\end{tabular}


Hasil pada tabel diatas menampilkan ratarata responden menjawab setuju dengan persentase $58,8 \%$, bahwa dosen mengemas isi pesan atau informasi di google classroom dengan sederhana sehingga mudah di pahami.

Tabel 10. Sumber pesan dapat dipercaya $\mathrm{n}=\mathbf{3 4}$

\begin{tabular}{|l|c|c|c|}
\hline Pernyataan & Frekuensi & Persentase & $\begin{array}{c}\text { Rata- } \\
\text { rata }\end{array}$ \\
\cline { 1 - 3 } $\begin{array}{l}\text { 4= Sangat } \\
\text { setuju }\end{array}$ & 7 & $20,6 \%$ & \\
\hline 3= Setuju & 25 & $73,5 \%$ & \multirow{2}{*}{$3,14 \%$} \\
\cline { 1 - 3 } $\begin{array}{l}\text { 2= Tidak } \\
\text { setuju }\end{array}$ & 2 & $5,9 \%$ & \\
\hline $\begin{array}{l}\text { 1= Sangat } \\
\text { tidak } \\
\text { setuju }\end{array}$ & 0 & $0 \%$ & \\
\hline \multicolumn{1}{|c|}{ Total } & 34 & $100 \%$ & \\
\hline
\end{tabular}

Hasil pada tabel diatas membuktikan sebagian besar responden menjawab setuju dengan persentase $73,5 \%$, bahwa setiap pesan atau informasi yang ada di google classroom memiliki sumber yang jelas dan dapat dipertanggungjawabkan, karena langsung berasal dari dosen yang bersangkutan.

Tabel 11. Waktu sesuai dengan kondisi $\mathrm{n}=\mathbf{3 4}$

\begin{tabular}{|l|c|c|c|}
\hline Pernyataan & Frekuensi & Persentase & $\begin{array}{c}\text { Rata- } \\
\text { rata }\end{array}$ \\
\cline { 1 - 3 } $\begin{array}{l}\text { 4= Sangat } \\
\text { setuju }\end{array}$ & 7 & $20,6 \%$ & \\
\hline 3= Setuju & 22 & $64,7 \%$ & \multirow{2}{*}{$3,00 \%$} \\
\cline { 1 - 3 } $\begin{array}{l}\text { 2= Tidak } \\
\text { setuju }\end{array}$ & 3 & $8,8 \%$ & \\
\hline $\begin{array}{l}\text { 1= Sangat } \\
\text { tidak } \\
\text { setuju }\end{array}$ & 2 & $5,9 \%$ & \\
\hline \multicolumn{1}{|c|}{ Total } & 34 & $100 \%$ & \\
\hline
\end{tabular}

Hasil pada tabel diatas menunjukkan sebagian besar responden menjawab setuju dengan persentase $64,7 \%$, bahwa pemilihan waktu oleh dosen dalam menyampaikan pesan digoogle classroom sudah sesuai dengan kondisi yang telah disepakati antara dosen dan mahasiswa .

Tabel 12. Mean Per Dimensi

\begin{tabular}{|c|l|c|}
\hline No. & \multicolumn{1}{|c|}{ Dimensi } & Rata-rata \\
\hline 1. & Penerima Pesan & $3,26 \%$ \\
\hline 2. & Isi Pesan & $3,05 \%$ \\
\hline 3. & Media Komunikasi & $3,15 \%$ \\
\hline 4. & Format Pesan & $2,75 \%$ \\
\hline 5. & Sumber Pesan & $3,14 \%$ \\
\hline 6. & Ketepatan Waktu & $3,00 \%$ \\
\hline
\end{tabular}

Berdasarkan tabel diatas, dapat diketahui bahwa dimensi penerima pesan memiliki rata-rata tertinggi sebesar 3,26\%, sedangkan dimensi format pesan memiliki dimensi terendah yaitu sebesar 2,75\%. Berikut tabel mean per indikator:

Tabel 13. Mean Per Indikator

\begin{tabular}{|c|l|c|}
\hline No. & \multicolumn{1}{|c|}{ Indikator } & Rata-rata \\
\hline 1. & Ketetapan penerima pesan & $3,26 \%$ \\
\hline 2. & Isi pesan objektif & $3,08 \%$ \\
\hline 3. & Isi pesan akurat & $3,02 \%$ \\
\hline 4. & $\begin{array}{l}\text { Media penyampaian pessan } \\
\text { sesuai dengan kebutuhan }\end{array}$ & $3,20 \%$ \\
\hline 5. & $\begin{array}{l}\text { Media penyampaian pesan } \\
\text { sesuai harapan antara } \\
\text { pengirim dan penerima pesan }\end{array}$ & $3,11 \%$ \\
\hline 6. & Format pesan jelas & $2,73 \%$ \\
\hline 7. & Format pesan singkat & $2,64 \%$ \\
\hline 8. & Format pesan sederhana & $2,88 \%$ \\
\hline 9. & Sumber dapat dipercaya & $3,14 \%$ \\
\hline 10. & Waktu sesuai dengan kondisi & $3,00 \%$ \\
\hline
\end{tabular}


Berdasarkan tabel diatas, dapat dilihat bahwa indikator ketepatan penerima pesan memiliki ratarata tertinggi yaitu sebesar 3,26\%, hal ini menunjukkan bahwa indikator ketepatan penerima pesan memiliki pengaruh lebih besar pada efektivitas google classroom sebagai media pembelajaran jarak jauh pada mahasiswa Ilmu Komunikasi UNJ angkatan 2018. Sedangkan indikator format pesan singkat memiliki rata-rata terendah yaitu sebesar 2,64\%, hal ini berarti bahwa indikator format pesan singkat memiliki pengaruh paling kecil pada efektivitas google classroom sebagai media pembelajaran jarak jauh pada mahasiswa Ilmu Komunikasi UNJ angkatan 2018.

\section{SIMPULAN}

Dapat disimpulkan bahwa google classroom sebagai media pembelajaran jarak jauh pada mahasiswa ilmu komunikai Universitas Negeri Jakarta angaktan 2018 sudah dikatakan efektif. Hal tersebut berdasarkan hasil jawaban dari responden, yang rata-rata menjawab setuju pada 6 dimensi efektivitas komunikasi yang ada di kuesioner, yaitu ketepatan penerima pesan, isi pesan, media komunikasi, format pesan, sumber pesan, dan ketepatan waktu.

Keenam dimensi memperoleh nilai rata-rata lebih dari 2,5\%. Dimensi penerima pesan memperoleh nilai tertinggi sebesar $3,26 \%$, dimensi isi pesan memperoleh nilai rata-rata sebesar 3,05\%, dimensi media komunikasi memperoleh nilai rata-rata sebesar 3,15\%, dimensi format pesan memperoleh nilai rata-rata sebesar
$2,75 \%$, dimensi sumber pesan memperoleh nilai rata-rata sebesar 3,14\%, dan dimensi terakhir yaitu ketepatan waktu memperoleh nilai rata-rata sebesar 3,005. Dapat kita simpulkan bahwa dimensi penerima pesan memiliki pengaruh paling besar sedangkan dimensi format pesan memiliki pengaruh paling sedikit dalam mempengaruhi efektivitas google classroom sebagai media pembelajaran jarak jauh pada mahasiswa Ilmu Komunikasi Universitas Negeri Jakarta angkatan 2018. Dengan demikian dapat disimpulkan bahwa responen yang merupakan mahasiswa Ilmu Komunikasi setuju bahwa google classroom merupakan media yang efektif digunakan oleh dosen untuk menyampaikan informasi atau materi seputar perkuliahan.

\section{DAFTAR PUSTAKA}

\section{Book}

Aida, N. R. (2020, Maret Kamis). Update Virus Corona di Dunia: 214.894 Orang Terinfeksi, 83.313 Sembuh, 8.732 Meninggal Dunia. Diambil kembali dari Kompas.com: https://www.kompas.com/tren/read/2020/03/1 9/081633265/update-virus-corona-di-dunia214894-orang

Efendi, Y., \& Utami, N. (2019). Pengukuran Efektivitas Pembelajaran Menggunakan Media E-Learning Google Classroom . CTIA.

Faruq, F., Dafik, Suharto, Fatahillah, A., \& Murtikusuma, R. P. (2018). Pengembangan Media Pembelajaran Interaktif Online Pokok Bahasan Barisan Aritmetika Berbantuan Microsoft Visual Basic. Kadikma ; Vol 9 No 2, 89-97.

Hakim, A. B. (2016). Efektifitas Penggunaan ELearning Moodle, Google Classroom dan Edmodo. I-SATEMENT: Information System and Technology Management 2(1).

Hardjana, A. (2000). Audit Komunikasi: Teori dan Praktek. Jakarta: PT. Grasindo. 
Koesmawardhani, N. W. (2020, Maret 17 ). Pemerintah Tetapkan Masa Darurat Bencana Corona hingga 29 Mei 2020. Diambil kembali dari Detiknews: https://news.detik.com/berita/d4942327/pemerintah-tetapkan-masa-daruratbencana-corona-hingga-29-mei-2020

Levy, P. (2001). Cyberculture, Electronik Mediations, V.4, Minneapolis,. Minn: London University of Minnesota Press.

Malhotra, N. K. (2010). Marketing Research : an applied orientation. USA: Prentice Hall.

McQuail, D. (2011). Teori Komunikasi Massa Edisi 6. Jakarta: Salemba Humanika.

Nova, S. P. (2018). Efektivitas Komunikasi Aplikasi Telegram Media Informasi Pegawai PT. Pos Indonesia (PERSERO) Kota Pekanbaru. JOM FISIP VOL.5, 1-11.

Putri, D. G. (2017). Communication Effectiveness Of Online Media Google Classroom In Supporting The Teaching And Learning Process At Civil Engineering University Of Riau. JOM FISIP Vol. 4 No. 1, 1-15.

Sabran, \& Sabara, E. (2019). Keefektifan Google Classroom Sebagai Media Pembelajaran. OJS UNM.

Simanihuruk, L., Simarmata, J., Sudirman, A., Hasibuan, M. S., Safitri, M., Sulaiman, O. K., et al. (2019). E Learning : Implementasi, Strategi dan Inovasinya. Medan: Yayasan Kita Menulis.

Syabrina, R. A. (2018). Efektivitas dan Efisiensi Komunikasi pada Penyelenggaraan Festival Damar Kurung Gresik Tahun 2017.

Watie, E. D. (2011). Komunikasi dan Media Sosial. The Messenger Vol 3. No 1, 69-75.

Zhang, M. (2016). Teaching With Google Classroom. Birmingham: Packt. 